\title{
DETERMINANTS OF EMPLOYEES' INVOLVEMENT AND THE ROLE OF THE LEADERSHIP STYLES IN ORGANISATIONAL COMMITMENT: EMPIRICAL FINDINGS FROM POLISH ENTERPRISES
}

\author{
Rafał Drewniak
}

\begin{abstract}
Background. The article points out those traits of character which should be found in good leaders, as well as the appropriate attitudes and actions taken by them, which are likely to be expected by their employees. Presently, with companies achieving more ambitious goals than ever, accompanied by rapidly developing technology and high demands from the specialist staff, the role of a good leader becomes crucial in building the social potential of any company. Undeniably, it is imperative in building the human factor in any company these days.

Research aims. The article studies leadership as the relationship between the situation model and the actual techniques applied in practice. The objective of the paper in this context is to emphasise those traits of character which should be found in good leaders and which make them more efficient.

Methodology. In order to identify the key traits a leader should have, a factual study was conducted among 156 employees working for different businesses. The study was conducted using an anonymous questionnaire. The second research technique was a direct individual interview with the CEOs from 5 different companies.

Key findings. The study identified a group of key conditions that significantly influenced the building of the degree of employees' involvement and contributed to enhancing the body of knowledge in the companies. The study indicated the following subjects: the employer-employee relationship, the role of employees in the decision-making process, their expectations, and the adopted style of leadership in the company. The obtained study results allowed to form a more practical view of the concept of leadership. According to the company's CEO, the effectiveness of leadership largely depends on the adopted managerial style.
\end{abstract}

Keywords: leadership, leadership style, organisational commitment, engagement.

* University of Science and Technology in Bydgoszcz. E-mail: rafal.drewniak@utp.edu.pl 


\section{THE NOTION OF LEADERSHIP: THEORETICAL BACKGROUND}

People have been interested in and fascinated by the notion of leadership for a long time. Having a new leader is always a welcome prospect, inspiring in employees hopes for change, and perceived by them as a potential cure for notorious problems. However, such expectations are verified by the organisation context: its structure, power distribution, local arrangements, etc. In other words, leadership should not be studied on its own, but always in the context in which it appears.

Current theories on leadership focus mainly on the leader's performance within the company's structure, implementing a future vision of the company, and actively involving employees in the process. This paradigm belongs to the Transformation Era in the leadership development (Van Seters \& Field, 1990). The representatives of this school, Tichy and Devanna (1996, pp. 271-280), stressed the initial role of building perspective and assigning competences, which would allow the employees to be involved entirely in achieving the company's goals. Today, the trend has been extended, so as to include cues for inducing positive expectations among employees as well. Undoubtedly, leadership is a complex process involving relationship, situation, and behavioural aspects (House \& Aditya, 1997, pp. 409-473).

Over the last decades many definitions of leadership have been suggested. One of them, proposed by Bass (1990), is particularly noteworthy, recognising the personality of the leader: leadership is a combination of such skills and traits of character, which allow the leader to influence and induce other people to perform effectively, and according to expectations. Indeed, the role of the bonds and the relationship between the leader and group members is crucial as these elements reflect on the leader's personality. Another common notion of leadership is that of influencing other people's actions, being a kind of social leverage that allows its user to induce desired and effective performance. In other words, leadership is encouraging action through (Bennis, 2009, pp. 135-140; Piotrkowski, 2006, p. 336):

- creating new patterns of behaviour,

- securing cues for behavioural change,

- changing the intensity of certain behaviours. 
Leadership consists in creating such emotions in employees, which determine their willingness to co-operate, create and achieve common goals, tasks and missions - irrespective of the type of power in a company, or employees' own reasons to participate (Yukl, 2008, pp. 708-722; Stabryła \& Wawak, 2014). Northouse (2003), on the other hand, highlight the four key aspects of leadership:

- leadership is a process,

- leadership is achieved through exerting influence,

- leadership is a group phenomenon,

- leadership is measured by achieving goals.

Hughes, Ginnett, and Curphy (2006) argue that it is the leader's duty to provide a group with suitable working conditions, making their work even more effective. Other researchers, namely Hogan, Curphy, and Hogan (1994), emphasise that the aim of leadership is obtaining the desired results through the work of others, which means that the basic task is to create coherent and task-oriented work teams. Thus, it can be said that efficient leaders are those who can build teams yielding fruit of their work through taking advantage of all possible situations.

On one hand, leadership can be defined as a process in which a person strives to exert pressure on a group, with a view to achieve common goals. On the other, it can be viewed through the Trait Leadership perspective. Instead of individual traits or skills of the leader, the process approach to leadership is based on the type of activity taking place between the manager/leader and his or her subordinates (Ogbonna \& Harris, 2000, pp. 766-788). In this sense, the managing actions are aimed at coordination and directing work in the group through setting up the hierarchy of dependencies, defining the structure of relationship, and showing interest in the team members' problems. Thus, leadership involves building power-structured relationships between people. However, other scholars stress that leadership should be understood as creating the meaning and the very nature of co-operation, which are the key to understand the reason for any endeavour. There is also the Character Approach, which maintains that the leader should exhibit certain traits of character, and be endowed with skills, which would justify his or her position as a superior (Jago, 1982; Hughes et al., 2006, pp. 7-9; Drath \& Palus, 1994; Bass, 1990).

According to Deming, the leader must be aware at all times that his or her job is to create the conditions which would secure employees' creativity, which in turn, would allow them to exhibit their own skills 
in proposing innovative changes that would benefit the whole company. Then, the notion of leadership must also include the idea of the total quality because there is a strict relationship between the effectiveness of leadership and embracing of the TQM directives (Ehigie \& Akpan, 2004).

\section{EMPLOYEE EXPECTATIONS TOWARDS LEADERS - THE HERSEY AND BLANCHARD SITUATION MODEL}

Contemporary conditions in the business environment make increased efforts of companies in the search for the key sources of competitive advantage. One of them is to have employees, who are fully dedicated and committed to the objectives of a company. The degree and scope of this engagement determine the performance, social behaviours and relationships between co-workers, as well as they promote the growth of innovation and improving the financial condition of companies. Therefore, in managing modern enterprises it is important not only to use the appropriate external stimuli to motivate employees, but above all to create conditions that foster their inner motivation. The leadership model proposed by Hersey and Blanchard (1996) is an example of the situational approach to leadership and deserves more attention. The situational leadership model, as the name implies, focuses on the situation aspects, and the leader's need to adjust his or her actions to the circumstances in which they operate. In other words, the leader's MOD (modus operandi) is a subject to constant adaptation depending on the situation (Chen \& Silverthorne, 2005). In this model, the leadership is comprised of two dimensions: directive and supportive. Only by the proper application of the two can a leader achieve success. However, the starting point for any leader should be the competence assessment of every group member. It will provide a foundation and help to determine the future mode of operation, based either on the directive or the participation factors. Both the circumstances and the dynamically changing employees' expectations are highly regarded in this model. It also assumes that employee skills and motivation change in time, therefore the proportion of the directive and supportive elements must be constantly verified and adjusted by the leader, depending on the situation, in order to manage the staff effectively. The style of leadership should reflect the operational patterns that leaders use to manage the employees, which can be defined as directive (task-oriented) 
and supportive (relation-based). The directive aspect of the leadership includes different types of influence exerted on subordinates, aimed at achieving a particular goal (e.g. setting up tasks, defining evaluation procedures, specifying participants' roles, drawing up schedules, etc.) The directive procedures require a leader to inform employees about the scope and the manner of work to be done as well as to assign responsibilities. The supportive procedures, on the other hand, are aimed at creating productive working atmosphere, making employees feel satisfied with their work, and stimulating interpersonal relationships within a team. This can be achieved through appropriate communication, providing emotional support and more direct or informal contact with employees (by expressing approval, welcoming and sharing new ideas, praising initiative, listening to feedback from the inside and the outside of the company). Focusing on both procedures, the situational approach to leadership can be subdivided into four models, depending on the layout of the directive and supportive procedures (Figure 1).

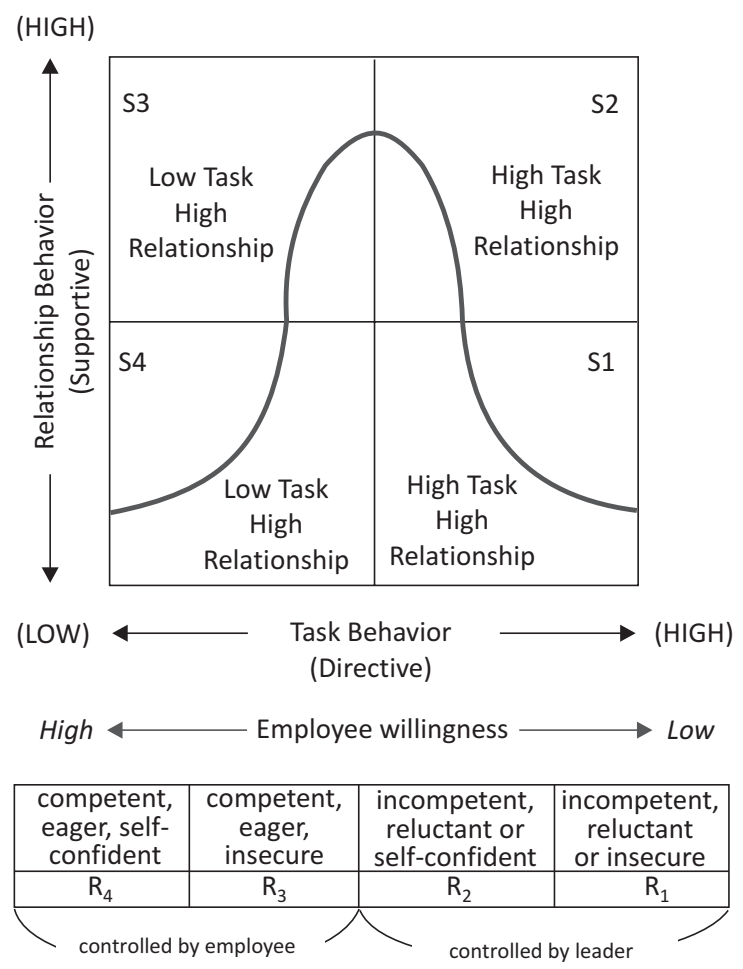

Figure 1. The situational type of leadership

Source: own study based on: Hersey \& Blanchard, 1996, p. 200; Northouse, 2003, p. 88. 
The Situational Leadership Model is based on the assumption that all employees strive to develop professionally. However, there is no leadership style that would guarantee equal development in all possible circumstances (Bass \& Bass, 2008). Importantly, how the employees are treated by the leader depends on how willing they are to participate in a particular project. It must be realised that only by using an appropriate style of leadership, one which is suited to an employee's individual requirements, will it be possible to achieve success. The four leadership styles, based upon the situational model, have been presented below (Hersey \& Blanchard, 2003, p. 115):

1. The directive style (S1) also known as "instruction", can be characterised as a less supportive and more directive an approach. It consists in giving clear and simple commands and requirements and careful monitoring of employees' work. The leader focuses on maintaining good communication and giving precise information paying little attention to the supportive elements.

2. The coaching style (S2), also known as "selling"; the emphasis is on both the task and the assistance given to employees; the leader provides advice and information and shares his or her knowledge. The aim is to persuade employees to perform certain tasks, and to help them become more independent so that in the future they would be able to perform similar tasks without the leader's assistance. The leader not only concentrates on communicating goals to employees and showing possible ways to attain them, but also takes into account the employees' social and emotional needs.

3. The supportive style (S3), also known as "participating" is characterised by high supportive roles and low directive ones. The leader maintains good communication with employees and responds immediately to their social and emotional requirements providing support. Employees have enough competence and experience to perform tasks, although they are still supervised by the leader. The employees' suggestions, involvement, and opinion sharing are very important.

4. The delegating style (S4) - the leader provides little direction or support, relying on employees' high motivation and professional skills. By adopting this style, the leader allows the employees to make independent decisions regarding the allocated task. 
The leader's supervision comes down to meticulous control. Leaving employees without any control, reward, or feedback is not recommended as they can easily lose motivation and the eagerness for self-development.

The Employee Readiness Scale (Figure 1) is crucial. It shows that the level of readiness depends on two basic factors: employees' eagerness and their ability to deliver.

$\mathrm{R} 1$ - employees are uncertain and perform their tasks reluctantly due to insufficient competence; however they are deeply involved in the project, the task is a welcome prospect and a challenge. In this case the leader controls the employees.

R2-employees have the basic knowledge and are competent enough to undertake the allocated task. However, they do not identify with the task. They are already experienced and possess necessary knowledge, but they have lost their eagerness.

R3-employees possess only average competence and qualifications to perform the task, they are hesitant and not very involved. Although they are responsible for carrying out the task, they lack the confidence, they doubt if they can perform the task unaided.

R4-employees are fully-qualified, involved, and eager to undertake the task. They are fully competent, skilled, and motivated to perform their duties.

Depending on the type of the task, subordinates can be characterised by different levels of readiness to undertake it. The author would like to emphasise that the eagerness does not depend on a person's character, age, or individual beliefs. The readiness depends on two factors: an employee's will to do something and their ability to do it. The latter should be understood as knowledge, experience and skills that the person needs in order to successfully perform a given task. The will, on the other hand, should be understood as self-confidence, involvement, and motivation to perform one's duties. Both concepts are different but entwined at the same time. In fact, the more motivated and willing to work the employees are, the better their skills and performance appear. On the other hand, their knowledge, experience, and competence strongly influence involvement and motivation (Hersey $\&$ Blanchard, 2003). The situational model is very popular, however, its style must be carefully adjusted, depending on the employee's willingness factor. Ignoring the style may yield negative consequences (Karaszewski, 2008, pp. 196-200). 


\section{THE NATURE AND THE SCOPE OF ORGANISATIONAL COMMITMENT}

Wide interest in the issue of employee involvement includes also an analysis and description of the factors affecting the level of employee engagement and its measurement. The essence of this phenomenon shows that the key determinant of commitment is the ability to dispose by an employee resources allocated to her/him in an independent manner, which in turn determines her/his innovation activities. It should be noted, however, that nowadays the scope of innovative activities extends beyond the boundaries of the product and its improvements. Increasingly, it concerns processes, implemented concepts, and other organisational changes that are conducive to improving a company. An employee who is engaged in work, identifies with the company, looks for challenges, and seeks to realise their professional ambitions, comply with their obligations, thinks innovatively and takes actions that will contribute to improving the competitiveness of the entire organisation. Experiencing such a state should be rewarded intrinsically (Antonic \& Hisrich, 2003; Robertson et al., 2012). Taking this into consideration, work engagement is a positive approach to responsibilities, full of interest and preoccupation, which is characterised by a dedication in the implementation of additional measures beyond the formally defined duties (Robertson et al., 2012; Armstrong, 2009). Bakker (2009) argues that engaged employees experience more positive emotions and have better mental and physical health, which also translates into higher productivity at work and better results (Salanova et al., 2005; Wright \& Cropanzano, 2000). Schaufeli (2008) argues that the concept of commitment to a job emerged on the basis of research related to burnout, or lack of well-being (Schaufeli et al., 2008). Muller (2012) writes, however, that the condition for the involvement of employees in their work is primarily their involvement in their lives, because without this, all the tools of motivation (awards, training, development, etc.) will not change the employee's attitudes. Furthermore, the involvement of employees requires departing from the dependency relationships that exist between an employer and an employee to peer relations where responsibility is bilateral in nature. Employee engagement has in fact rooted in positive attitudes to their superiors and a sense of responsibility for the results of their own work. It is now 
recognised that a person goes beyond the traditional understanding of work, which is regarded not only as a source of income, but as a place to pursue their own development goals and aspirations, and a place where an employee can confirm his/her own value. This is facilitated by a deep revitalisation of a company, which may be regarded as a key determinant of building staff commitment. It involves making strategic action at a general level, building a new corporate culture, innovative methods of communication, new values, and creating the ground for employee initiatives (Burns, 2005).

Other proposals treat the employee involvement as a very wide spectrum, as the overarching concept of containing different types of involvement, e.g. involvement as a personal feature of an individual, commitment to work, attachment to a specific organisation (Macey et al., 2009). Commitment is the attitude of an employee to work, organisation, profession, which, regardless of other factors, has an impact on his/her actions (Herrbach, 2006). It gives direction of employee behaviours and can lead to sustaining them, even in a situation of the conflict of motives and attitudes.

The nature and extent of staff involvement should be analysed on the basis of the distinction between the general concept of commitment (employee engagement, job involvement) and organisational commitment. The first one involves the objective conditions which determine an employee's decision to remain in the workplace and conscientiously fulfil their obligations. It is linked to a desire to maintain a job, fear of losing it, and too high costs of changes of employment. The second one i.e. organisational commitment is commonly understood in terms of personal identification with the goals and values of a company, readiness to make efforts for a company and desire to continue being a member of a company. It is a psychological force that connects employees with organisations and makes them feel that leaving a job is perceived as less attractive (Johnson et al., 2009). It is manifested in a certain action, which has both an emotional component (people generally feel positive emotions in relation to the subject of their involvement) and rational (the commitment is an act of choice, a decision, usually made with the conviction to fulfil the obligations arising from this commitment). However, due to the fact that engagement requires efforts, most people take it with the expectation of reciprocity and the assumption that in return for their commitment, they will get something what is important for them (Vance, 2006). 
The above analysis shows that the scope and nature of staff involvement may be characterised in various ways, depending on how it is perceived by a company and that it takes priority over other activities of a company. There is also no consensus on the elements influencing employee engagement. Among the components of staff involvement, the most common are the following: fit for the job, a variety of tasks, rewards and recognition, development opportunities (Crawford et al., 2010), or top management commitment, leadership, team work, communication, training, gratitude, measurement. Involvement is a positive attitude of employees towards an organisation and its values, manifested by the awareness of organisational situation and cooperation in order to improve results and for the benefit of the organisation (Crawford et al., 2010; Robinson et al., 2004).

Simultaneously, the attention should be paid to the multidimensional character of this term, which in practice means the necessity of using specific categories, which make up the whole organisational commitment. In this sense, we can be distinguish three major dimensions of commitment (Allen \& Meyer, 1990; Meyer \& Herscovitch, 2001):

- affective: emotional attachment to an organisation, motivation, identification with it; the degree to which a person is psychologically associated with the employing organisation by feelings of loyalty, sympathy, kindness, affiliation, sentiment, satisfaction, etc.; this commitment is related to the reluctance to incur additional costs of searching for a new employer;

- duration: awareness of the costs associated with leaving an organisation; the degree to which a person is convinced about the necessity to remain in the organisation because of the high cost of living; this is related to the benefits which an employee receives as part of the work;

- normative: a sense of moral obligation to remain in a company; the degree to which a person is psychologically associated with the employing organisation through internalisation of objectives, values, and mission.

It is important that these aspects are considered as components of engagement, since all these elements may also reflect the relationship between an employee and a supplier in varying degrees. The interest in employee commitment is a result of the perceived consequences for organisations ranging from the behaviour of employees (fluctuation, job satisfaction, and citizenship behaviour) to the relationship between 
the level of employee engagement and company performance: increasing employee engagement leads to improved customer satisfaction, revenue growth, or improvement competitive position (Roberts \& Davenport, 2002). Relationships characterised above lead to undertaking by an organisation the activities that strengthen employee commitment and thus it becomes important to study the antecedents of this specific relationship between an employee and the company. Employee involvement in capacity building of the company can be an important source of competitive advantage of modern enterprises, thanks to the acquisition of new knowledge, both explicit (formal) and tacit (implicit).

\section{DETERMINANTS OF EMPLOYEES' COMMITMENT}

Building an emotional bond with an employee is a bilateral relationship, hence an organisation should go beyond waiting passively for a high degree of employee involvement, but it should actively shape the relationship, which consists of a set, sequence, or sequence of interactions manifested in the operations of both parties. It may be said that building employee engagement is conditional upon the knowledge of four groups of factors (Table 1).

To achieve the objective of this paper, empirical studies were conducted, which included 156 employees, working in 5 manufacturing companies. The aim of the study was to determine the instruments used to build employee engagement. The study was conducted using an anonymous questionnaire. It was assumed in the study that this group of employees had the greatest knowledge of the most effective factors used in the surveyed enterprises that supported their involvement. The study identified a group of key conditions that significantly influenced the building of the degree of employees involvement in the surveyed enterprises and contributed to enhancing the body of knowledge in the companies under the study. The findings are presented in Figure 2.

The study showed that the majority of respondents (57\%) indicated the stability of employment and opportunities for development and promotion (51\%) as key determinants of building their engagement in relation to the employer. Two additional key factors of employee involvement were identified: reward (49\%) and providing and maintaining a friendly 


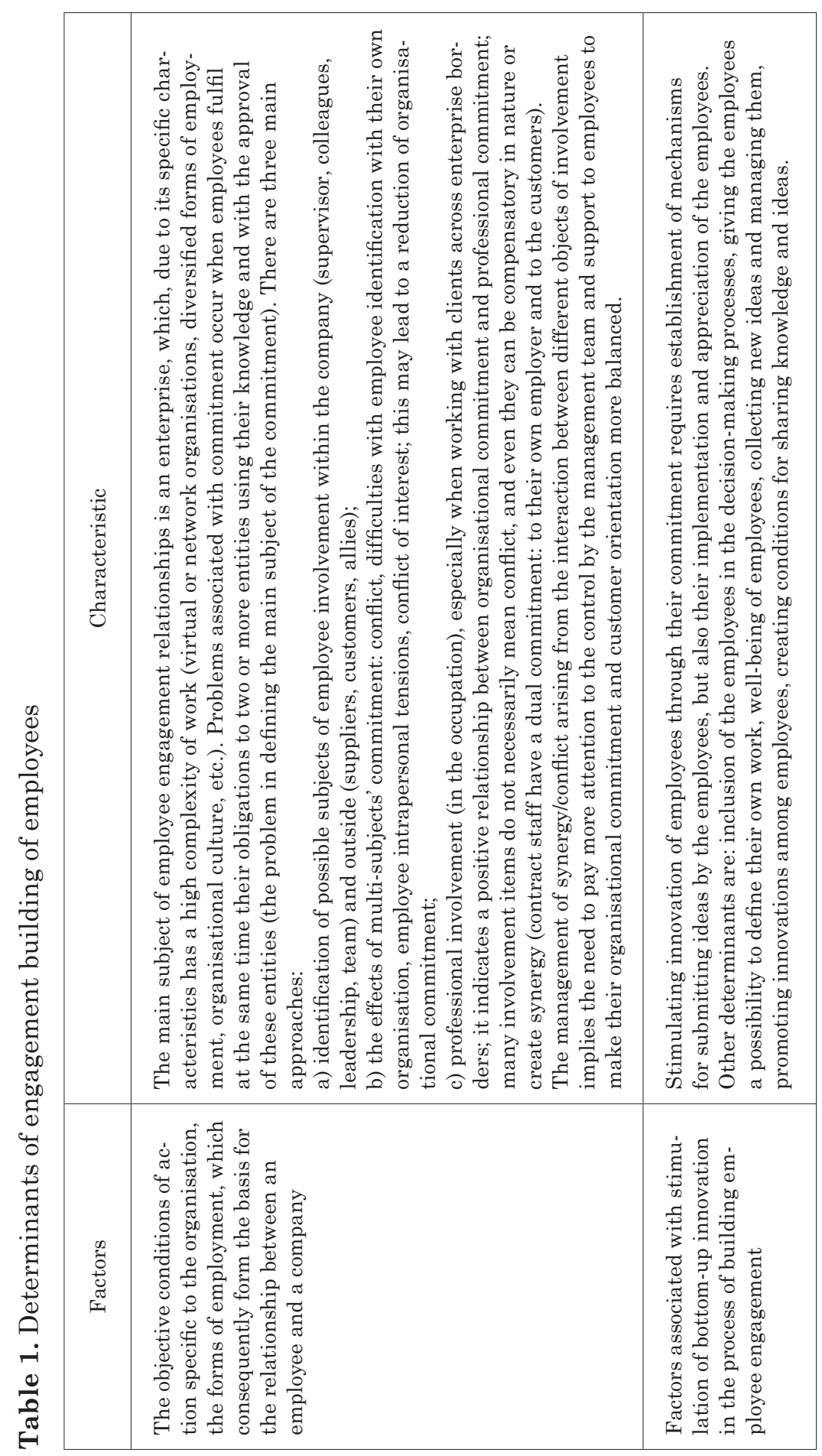




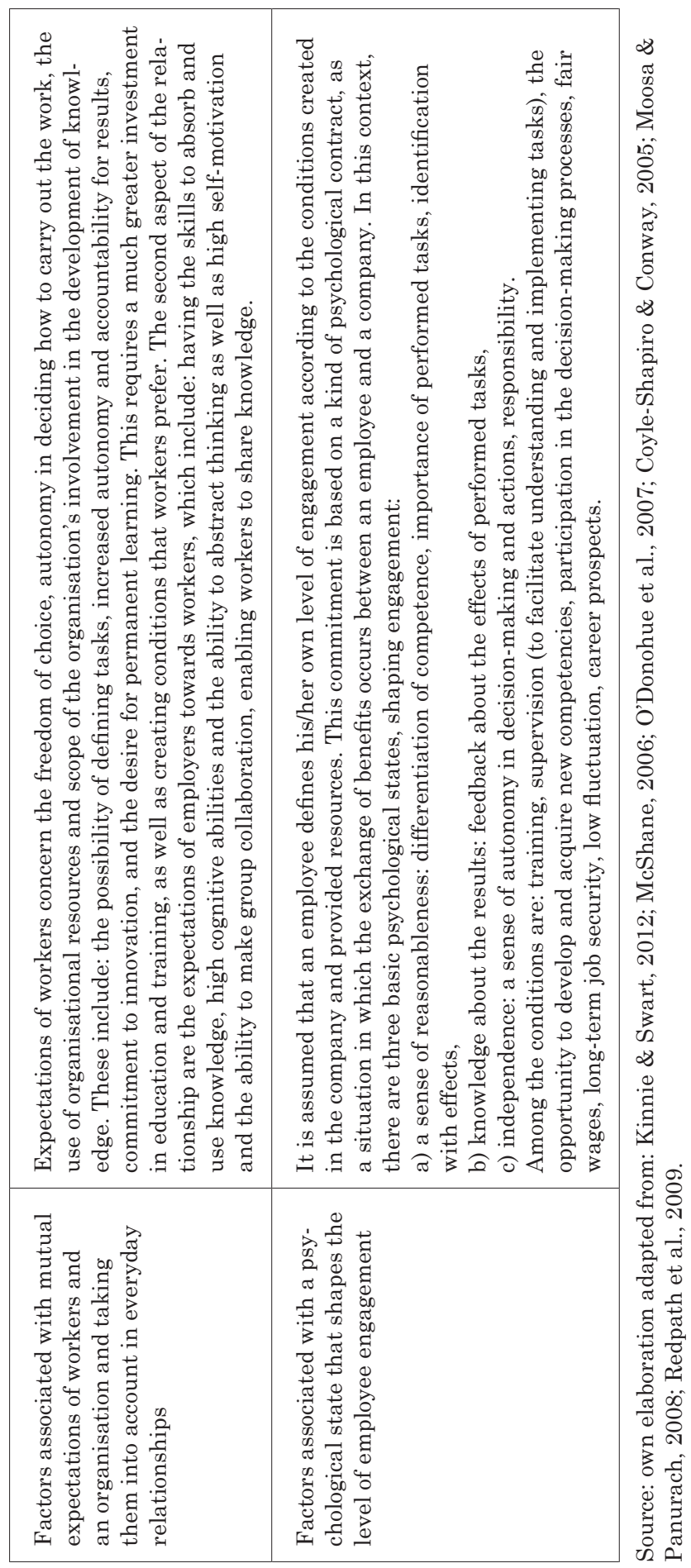




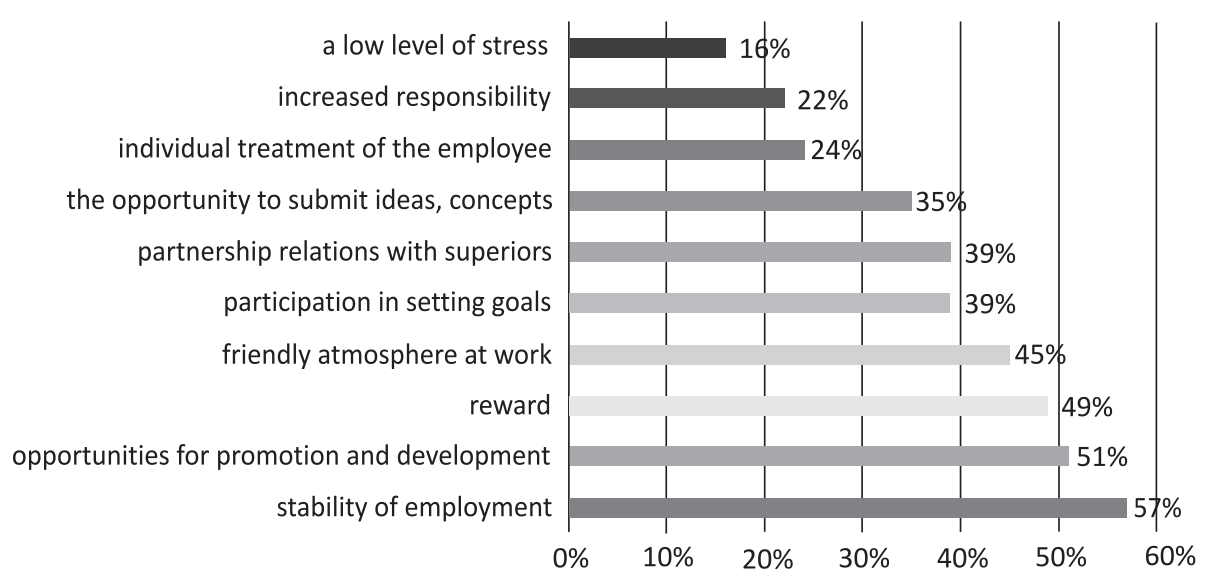

Figure 2. Determinants of employee engagement - the results of own study Source: own study based on empirical research.

atmosphere at work (45\%). It should be noted that while the reward and the atmosphere at work are often listed among the stimuli to engage and motivate employees, the stability of employment is not very often indicated as a key determinant of creating employee involvement. This may be due with uncertainty of the economic situation, where in times of crisis employees are more interested in maintaining employment. In the second group of factors that determine building commitment the possibility of the participation of employees in setting business objectives and the existence of partnership relations with superiors were indicated (listed by 39\% of the respondents). This highlights the significance of peer relationship between employers and employees to increase employee involvement which means that the leadership features here are more important than management skills. The respondents also pointed to the importance of action which would enable them to raise their own ideas and improvements (35\%). It applies to creating the conditions that make possible to stimulate grassroots innovativeness among employees. However, it is important to establish conditions to implement improvements recommended by employees. This applies to various kinds of changes including product, process, and organisational innovations. To a lesser extent, the study indicated the role of an individual approach to an employee (24\%) and increasing the responsibility of employees by delegation of responsibilities and authority (22\%). It seems, however, that these factors will play an increasingly important role in maintaining valuable employees in the 
organisation due to working conditions, characterised by the increasing pressure of time and the multidimensiality of duties. At the same time it is assumed that the importance of increasing the responsibility of employees will grow as building a sense of awareness of employees about the impact on the functioning of the company and co-responsibility for its future have positive effects on integration and identification of employees with the company. Moreover, the respondents pointed out the activities that would reduce the level of stress at work (16\%). It should be noted that a lot of tension and stress among employees is harmful to building their involvement in the creation of knowledge and innovation for a company.

A similar study, that was conducted in Poland (Samul \& Saczyńska-Sokól, 2013) indicated the instruments used by Polish companies to build the commitment of managerial staff and ways to measure the commitment level in small businesses. The research shows that only $6 \%$ of small businesses do not take any action aimed at increasing the involvement of its managers. Furthermore, most of the surveyed companies (62\%) offer its employees stability of employment, slightly less (55\%) growth opportunities, and salary depending on the results achieved. Among the other instruments used to stimulate the managers engagement are: ensuring interesting work, in accordance with the competences of the employee (42\%), creating a friendly atmosphere at work (40\%), and formation of partnership relations (19\%). The vast majority of companies (71\%) use only a few tools and one fifth of companies take more action (from 5 to 7 ) in order to improve employee engagement, and only a few companies affects the managers commitment in one way.

\section{MANAGER/LEADER CONDUCT - INTERVIEW RESULTS}

In order to identify the key characteristics a leader should have, an empirical study was carried out in selected businesses in Poland. The research technique was the direct individual interview with the CEOs from 5 different companies. It focused on issues such as managing human resources in general, and the relationship between managers and employees. The questions concerned the adopted style of management, motivation techniques, and methods used for resolving conflicts. The interviews allowed to form conclusions about how the management 
techniques used by managers in companies can influence their overall success.

The interviews provided with the following observations: the motivation system, which was introduced by the company management, has been in operation for many years. The employees are paid a regular salary and bonuses, depending on their individual output. Another incentive is choosing of "The employee of the month", where the whole team decide who deserves to be rewarded for being the best professional. The production plans are drawn up with line managers or independent experts. Only the best methods which guarantee meeting the targets are taken into consideration. All circumstances such as technical potential or the risk factor are carefully considered. Planning new targets always starts with summing up of the previous month's results. In this way, theoretical assumptions can be verified, and possible corrections can be made. Having experts present during such meetings is important not only for task verification purposes but also for the error analysis and its elimination. This mechanism helps employees become more independent and professional. Maintaining the regular meetings is perfect for building teamwork, smooth integration of new employees, and increasing responsibility for the results of the whole business. What is more, certain companies offer two types of training courses: compulsory (workplace-dependent) and voluntary (dependent on individual career paths). Each worker receives a training roster based either on workplace requirements or their individual needs. The training is planned so as not to disturb employees' work schedule. The training progress is verified at the beginning of each three-month period.

The interviews also showed that paying attention to employees' individual requirements can be beneficial and lead to a better use of resources. Making staff feel understood and, if possible, meeting their expectations, produces a similar reaction; they are eager to work harder and more efficiently. It also makes them communicate their concerns instantly, ask for advice or seek particular action. The leader remains open to employee's suggestions and tackles arising problems in spite of occasional confrontation.

The interviews also provided feedback on the adopted management style, which is comprised of several key concepts. Fulfilling a task remains the ultimate goal but it can be achieved through skilled and flexible team management. Successful team management is a skill 
that can be learnt through experience and by knowing one's team members. These two elements are crucial for achieving ambitious goals. Interpersonal conflicts are resolved through discussion and mediation. However, if a conflict arises, resolving to giving instructions and commands is counter-productive and unlikely to help resolve the problem. In particularly complex situations, the official disciplinary procedures may apply (take the form of various disciplinary actions or financial punishment).

Both the employees and the employer were positive that interpersonal communication works well in the company. It would not be possible without the regular daily contact between staff and the management, to discuss production plans, etc. Formal communication (in the presence of a third party) is only required to resolve conflicts or when the authorities continue to ignore problems reported by workers.

It must be said that the chosen style of management brings positive results. The diverse and optimal leadership has proved successful for both the company and its employees, who eagerly identify with the company thanks to the appropriate motivation system, the potential to influence the decision-making process, good interpersonal communication, and a friendly atmosphere. The company, on the other hand, sets itself more and more ambitious targets, becoming the market leader and securing new orders. Good leaders know how to lead their junior followers, how to show them the right path and teach to become independent in their endeavours. At the same time, the leaders identify their own goals with the subordinates and the company.

\section{THE SUPERIOR-SUBORDINATE RELATIONSHIP - SURVEY RESULTS}

As mentioned above, a group of 156 employees was examined in the course of the study. In fact, the aim of the study was to identify these characteristics in leaders, which make them more efficient, and to show employees' expectations with regards to the operation and the conduct of their manager. The technique of the study was a questionnaire, distributed among the 156 employees working in production departments of 5 different medium-size enterprises. Generally, the surveyed group spoke favourably about the management method adopted by their superiors. The full results of the survey are presented in Figure 3. 


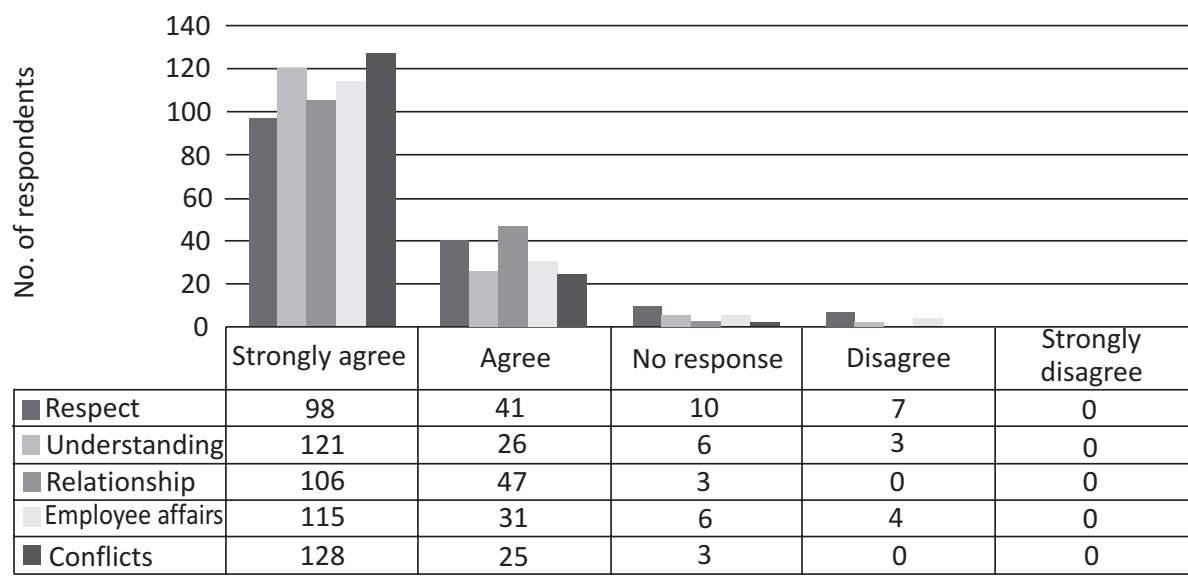

Figure 3. Feedback on respect, relationship, understanding, and conflicts between subordinates and superiors

Source: own study based on research results.

Undeniably, a proper working atmosphere significantly improves the working environment. Employees who feel comfortable at the work place start to identify themselves with it, and, gradually, the company's goals become their own. They realise that without maintaining good relationships with co-workers, they are run the risk of their work place becoming forced labour. The study proved that as many as $89 \%$ of the polled believed that the manager maintains proper relationship with the employees, understands and responds to their needs with a smile, while $78 \%$ of the respondents claimed they have no problems communicating with their superiors, who actively try to help employees solve their problems. 115 respondents declared that they are "satisfied" with the manager's performance, while $20 \%$ are "quite satisfied". Building positive relationships between staff members is not the most important thing but it can significantly improve the working atmosphere. The same can be said about communication. Unfortunately, conflicts between staff members are sometimes unavoidable, but the study results suggest how they may be tackled. While only three persons failed to provide a satisfactory answer, the wide majority of the respondents declared that conflicts are handled well (82\%) and satisfactorily (16\%).

Evaluation of the decision making process. The researchers were very interested to find about employees' ability to propose new ideas, especially those regarding the whole company, and to influence the managers (Figure 4). 


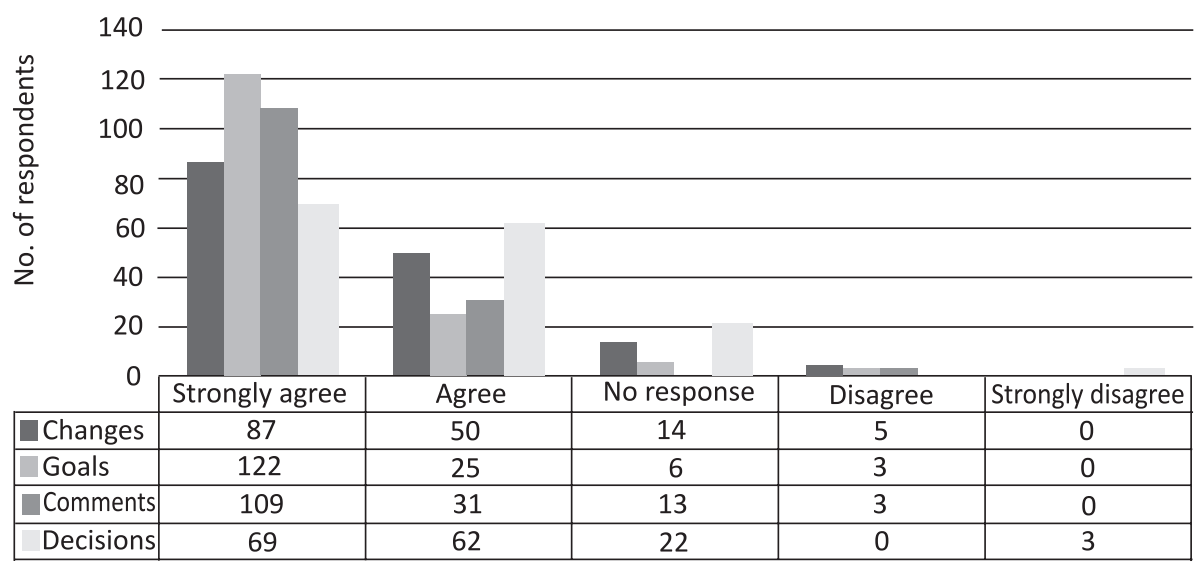

Figure 4. Decision making process in the company - submitted answers Source: own study based on research results.

Typically, employees have little influence on the decision-making process in companies. Decisions are normally made by company authorities: top managers, directors, and the managing board. However, there are businesses which highly value opinions from junior staff, because they are the ones who learn about typical problems firsthand. For example, production workers can influence decisions made by the foreman when work does not progress according to expectations. Figure 4 shows that the manager respects his subordinates and ascertains that his staff are acquainted with the changes affecting their work. Setting goals together has a positive influence on teamwork. Knowing one's own potential and workplace allows to set more realistic goals. In the studied company, $78 \%$ of the employees claimed that both employees and the manager set the goals together. Such work organisation may help the company achieve better results and, generally, become more successful.

Opinions submitted by employees are a valuable source of information which may reveal potential obstacles in the work system. After all it is the staff that face problems first. If the authorities are alerted in good time, they may take steps aimed at addressing the malfunctions and delays. $70 \%$ of respondents admitted that managers consider and value employees' comments and $8 \%$ did not provide a satisfactory answer.

Management styles adopted by the leader. In the study, the researchers also attempted to match managers to particular management styles. The results have been presented in Figure 5. 


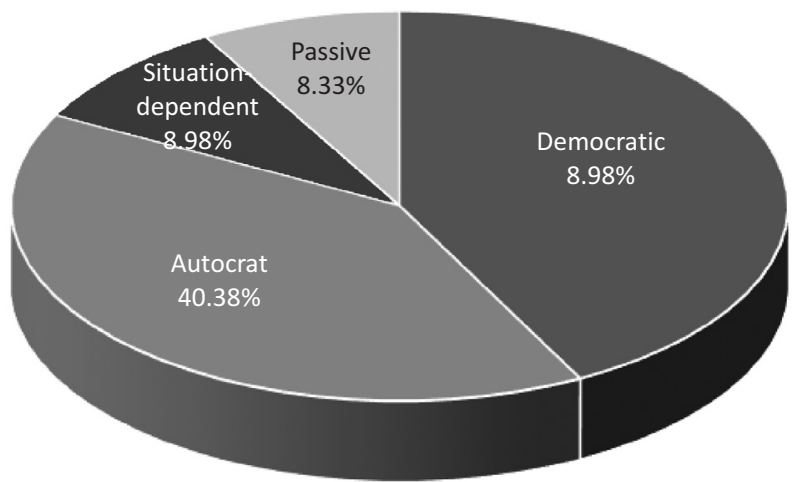

- Democratic - group as a whole. The leader respects group members' suggestions.

- Autocrat - the leader is the most important. The leader makes decisions, does not take part in work.

- Passive - the leader allows employees to plan and organise tasks of the group and does not make decisions.

- Situation-dependent.

Figure 5. Management styles adopted by managers

Source: own study based on research results.

The majority of the respondents see their managers as democrats (42.31\%) or autocrats (40.38\%), while $8.98 \%$ believed that the adopted style is situation-dependent (Figure 5). Such results are surprising considering that they all relate to the same manager. It can be argued that the manager uses different management styles depending on an employee or a situation.

Another reason for such discrepancies may be that the respondents had problems defining precisely what managerial techniques had been adopted. The next question in the questionnaire also related to the style of management. The results were as follows: $78 \%$ of the polled decided that their manager used the Executive style (being demanding towards the staff and himself/herself), 10\% claimed that it was the Developer style (trusting, delegating his authority to staff), another $10 \%$ believed that the manager represented the Benevolent Autocrat (gets projects done without alienating people), while only $2 \%$ opined that their manager adopted the Bureaucrat style (characterised by high attention to formal procedures and carefully scrutinising the staff).

The analysis of the collected data leads to the following conclusion: the manager is very demanding and acts according to the Executive Managerial model. $78 \%$ of the respondents believed that the manager is able select the appropriate working team and that his decisions are very effective. 
Employees' expectations towards superiors. The company authorities understand that apart from being the workforce, employees possess considerable potential. What is more, they need a good working environment to achieve personal and the company's goals. The researchers also attempted to decide what employees expect from their superiors (Figure 6). This is particularly important because the cooperation with the manager has a considerable impact on the work. Employees who expect a certain response or action from their manager are involved in the life of the company and identify with their workplace.

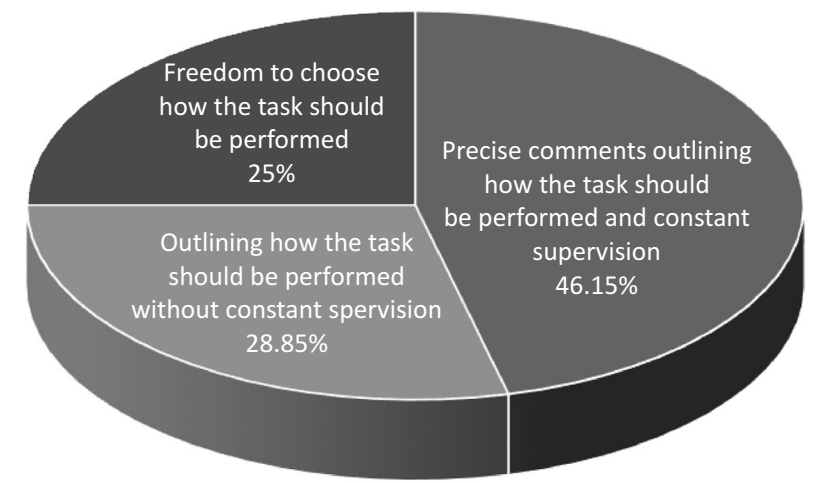

Figure 6. Employee's expectations towards their superiors Source: own study based on research results.

72 respondents out of the whole group declared that when working on a project they expect solid guidelines and supervision from their manager. While further $28.85 \%$ also expect precise commands, they stressed that they appreciate more freedom in their actions at the same time. Only $25 \%$ of those taking part in the survey admitted they would like total independence when performing their tasks, without any form of supervision whatsoever.

\section{DISCUSSION AND FURTHER RESEARCH DIRECTIONS}

Shaping the involvement of knowledge workers is one of the most important tasks of modern enterprises, being one of the key sources of competitive advantage. This specific, and simultaneously a positive resource of relationships between a company and a worker determines 
his/her efforts for the organisation and high intrinsic motivation. Building commitment of knowledge workers needs to take into account the objective factors relating to organisational conditions and the type of business a company operates in. The changes taking place in the organisational structure of enterprises, increasing employment flexibility, reorganisation of companies result in a situation when an employee works for many organisations and, therefore, he or she engages in relationships with a number of employers. This may lead to a conflict of interests, which requires high competence from managers in the field of human capital management in order to maintain positive relationships and achieve the synergies from managing the knowledge workers' commitment.

Knowledge employees often determine the success of a company and often represent a significant source of its competitive advantage (especially in the fields of advanced technologies). This is mainly due to the possession and sharing their hidden (implicit) knowledge. Therefore, nowadays, hiring knowledge workers is becoming a key determinant of the company success and the importance of such workers can be seen by the degree of ease or difficulty to replace them. It is extremely important to combine building employee engagement with factors related to employee career development, to create favourable opportunities for learning and acquiring new skills, which should lead to an increase in the possibility of introducing product, organisational and process innovations. This is the most important condition for organisational commitment of this group of employees.

It should be noted, however, that the list of factors determining the involvement of employees should not be closed. In fact, the process of shaping the commitment is continuous in nature with systematic and situational approach. It is characteristic for this process to take into account the incorporation of new elements that contribute to a higher level of employee engagement and stimulate their positive emotions associated with the workplace.

The obtained study results allowed to form a more practical view of the concept of leadership. According to the companies' CEOs, the effectiveness of leadership largely depends on the adopted managerial style. Maintaining appropriate relationships between employees is a prerequisite which can guarantee a comfortable working atmosphere, and a dedicated team of professionals who understand each other and deliver high-quality output. Managers can choose from different managerial 
styles according to their preference, however it seems that adopting a mixed approach seems the most reasonable as it can be adjusted to the requirements of individual employees. Thus, before making any decisions, leaders should get to know their team first, discover what motivates its members and find out about their personal expectations regarding the workplace.

The theoretical model of leadership, analysed in this paper, recognises the importance of the situation factors, which require leaders to adapt their strategy to the circumstances in which they operate. It focuses on both the circumstances, and the ever-changing expectations of employees. As a result, the actions undertaken by leaders are a subject to constant adaptation, depending on the circumstances. This approach looks at leadership in two dimensions: directive and supportive. This division is based on the idea that skills and motivation of employees change in time, requiring the directive and the supportive element in the leadership strategy to change accordingly. Only the proper use of the situation-dependent strategies can secure effective leadership. A leader must strive to create such working conditions, so that employees would have the opportunity to develop their creativity, and use their potential to help the company by proposing innovation. Thus, the leadership style defines certain patterns that leaders exert on employees.

I consider that the natural evolution mechanism adopted by the company, which means advancing gradually from junior to more senior positions, allows the employees to get thoroughly acquainted with the company policies. The promotion procedures are clearly explained. The study proved that the employees strongly identify themselves with the company, and express positive opinions about it. What is more, they perceive the goals of the company as their own. Thanks to the application of special tools, they are highly-motivated and, therefore, more effective in their endeavours, which bring the desired effects. The superiors strive to get to know and understand their employees, so that they can adopt the best suited, individual style of leadership.

Currently, with companies achieving more ambitious goals than ever, accompanied by the rapidly developing technology and high demands from the specialist staff, the role of a good leader becomes crucial in building the social potential of any company. A competent leader, despite numerous obstacles, should be able to create such work environment in which the staff will successfully perform their 
duties and help the company to develop. In the light of the above, it becomes clear that the leader should arrange compulsory and voluntary training meetings for staff in order to give them a chance for a constant self-improvement. Learning professional skills and accumulating experience through constant work and training result in employees who identify with the company, and gradually increase their job satisfaction because they know that the company relies on them for their knowledge.

\section{REFERENCES}

Allen, M.J. \& Meyer, J.P. (1990). The measurement and antecedents of affective, continuance and normative commitment to the organization. Journal of Occupational and Organizational Psychology, 63, 1-18.

Antonic, B. \& Hisrich, R. (2003). Clarifying intrapreneurship concept. Journal of Small Business and Enterprise Development, 10(1), 7-24.

Armstrong, M. (2009). Zarzqdzanie wynagrodzeniami. Kraków: Wolters Kluwer.

Bakker, A.B. (2009). Building engagement in the workplace. In: C. Cooper \& R. Burke (eds.), The Peak performing Organization. Routledge: Oxford, 50-72.

Bass, B.M. (1990). Bass and Stogdill's Handbook of Leadership: A Survey of Theory and Research. Free Press: New York.

Bass, B.M. \& Bass, R. (2008). The Bass Handbook of Leadership: Theory, Research, and Managerial Applications. Free Press: New York.

Bennis, W. (2009). On Becoming a Leader. Basic Book: New York.

Burns, P. (2005). Corporate Entrepreneurship. Building an Entrepreneurial Organization. Palgrave: New York.

Chen, J. \& Silverthorne, C. (2005). Leadership effectiveness, leadership style and employee readiness. Leadership \& Organization Development Journal, 26(4), 280-288.

Coyle-Shapiro, J. \& Conway, N. (2005). Exchange relationships; examining psychological contracts and perceived organizational support. Journal of Applied Psychology, 90(4), 774-781.

Crawford, E.R., LePine, J.A. \& Rich, B.L. (2010). Linking job demands and resources to employee engagement and burnout: a theoretical extension and meta-analytic test. Journal of Applied Psychology, 95(5), 834-848.

Drath, W.H. \& Palus, C.J. (1994). Making Common Sense: Leadership as Meaning-making in a Community of Practice. Center for Creative Leadership: Greensboro, NC. 
Ehigie, B.O. \& Akpan, R.C. (2004). Roles of perceived leadership styles and rewards in the practice of Total Quality Management. The Leadership \& Organization Development Journal, 25(1), 24-40.

Herrbach, O. (2006). A matter of feeling? The affective tone of organizational commitment. Journal of Organizational Behavior, 27, 629-643.

Hersey, P. \& Blanchard, K. (1996). Management of Organizational Behavior: Utilizing Human Resources. Englewood Cliffs.

Hersey, P. \& Blanchard, K.H. (2003). Situational leadership. In: Business Leadership. Jossey-Bass Reader: San Francisco.

Hogan, R.T., Curphy, G.J. \& Hogan, J. (1994). What do we know about personality: leadership and effectiveness? American Psychologist, 49, 493-504.

House, R.J. \& Aditya, R.N. (1997). The social scientific study of leadership: Quo vadis? Journal of Management, 23(3), 409-473.

Hughes, R.L., Ginnett, R.C. \& Curphy, G.J. (2006). Leadership: Enhancing the Lessons of Experience. McGraw-Hill: New York.

Jago, A.G. (1982). Leadership: Perspectives in theory and research. Management Science, 3, 315-336.

Johnson, R.E., Groff, K.W. \& Taing, M.U. (2009). Nature of the interactions among organizational commitments: Complementary, competitive or synergistic? British Journal of Management, 20, 431-447.

Karaszewski, R. (2008). Przywództwo w środowisku globalnego biznesu. TNOiK: Torun.

Kinnie, N. \& Swart, J. (2012). Commitment to whom? Professional knowledge worker commitment in cross-boundary organisations. Human Resource Management Journal, 1, 21-38.

Macey, W.H., Schneider, B., Barbera, K.M. \& Young, S.A. (2009). Employee Engagement: Tools for Analysis, Practice, and Competitive Advantage. Oxford: Wiley-Blackwell.

McShane, S.L. (2006). Organizational Behavior. New York: McGraw-Hill.

Meyer, J.P. \& Herscovitch, L. (2001). Commitment in the workplace: Toward general model. Human Resource Management Review, 11, 299-326.

Moosa, N. \& Panurach, P. (2008). Encouraging front-line employees to rise to the innovation challenge. Strategy \& Leadership, 36(4), 4-9.

Muller, G. (2012). Employee engagement - a new paradigm. Human Resources Management International Digest, 20(2), 3-5.

Northouse, P.G. (2003). Leadership: Theory and Practice. Sage: Thousand Oaks.

O'Donohue, W., Sheehan, C., Hecker, R. \& Holland, P. (2007). The psychological contract of knowledge workers. Journal of Knowledge Management 11(2), 73-82. 
Ogbonna, E. \& Harris, C. (2000). Leadership style, organizational culture and performance: empirical evidence from UK companies. International Journal of Human Resource Management, 11(4), 766-788.

Piotrkowski, K. (2006). Organizacja i zarzadzanie. Warszawa: AlmaMer.

Redpath, L., Hurst, D. \& Devine, K. (2009). Knowledge workers, managers and contingent employment relationships. Personnel Review, 38(1), 74-89.

Roberts, D.R. \& Davenport, T.O. (2002). Job engagement: Why it's important and how to improve it. Employment Relations Today, 29(3), 21-29.

Robertson, I.T., Birch, A.J. \& Cooper, C.L. (2012). Job and work attitudes, engagement and employee performance: Where does psychological well-being fit in? Leadership \& Organization development Journal, 33(3), 224-232.

Robinson, D., Perryman, S. \& Hayday, S. (2004). The Drivers of Employee Studies. Brighton: Institute For Employment Studies.

Salanova, M., Agut, S. \& Peiro, J.M. (2005). Linking organizational recourses and work engagement to employee performance and customer loyalty: The mediation of service climate. Journal of Applied Psychology, 90, 1217-1227.

Samul, J. \& Saczyńska-Sokół, S. (2013). Tworzenie i pomiar zaangażowania kadry kierowniczej w małych firmach. In: Z. Wiśniewski (ed.), Zarzadzanie zasobami ludzkimi w małych i średnich przedsiębiorstwach. Warszawa: Wolters Kluwer, 356-364.

Schaufeli, W.B., Taris, T.W. \& Van Rhenen, W. (2008). Workaholism, burnout and engagement: three of a kind or three different kind of employee well-being. Applied Psychology: An International Review, 57(2), 173-203.

Stabryła, A. \& Wawak, S. (2014). Problemy zarzqdzania organizacjami w społeczeństwie informacyjnym. Kraków: Mfiles.

Tichy, N.M. \& Devanna, M.A. (1996). The Transformational Leader. New York.

Van Seters, D.A. \& Field, R.H.G. (1990). The evolution of leadership theory. Journal of Organizational Change Management, 3, 29-45.

Vance, R.J. (2006). Employee Engagement and Commitment. A Guide to Understanding, Measuring and Increasing Engagement in your Organization. Alexandria, USA: SHRM Foundation.

Wright, A. \& Cropanzano, R. (2000). Psychological well-being and job satisfaction as predictors of job performance. Journal of Occupational Health Psychology, $5(1), 84-94$.

Yukl, G.A. (2008). How leaders influence organizational effectiveness. The Leadership Quartely, 19, 708-722. 


\title{
DETERMINANTY ZAANGAŻOWANIA PRACOWNIKÓW \\ - ROLA STYLU PRZYWÓDZTWA W BUDOWANIU ZAANGAZZOWANIA ORGANIZACYJNEGO: WYNIKI BADAŃ Z POLSKICH PRZEDSIĘBIORSTW
}

\begin{abstract}
Abstrakt
Tło badań. W artykule dokonano charakterystyki cech oraz odpowiednich postaw skutecznego przywódcy w kontekście oczekiwań pracowników. Współcześnie, gdy firmy wciąż realizują coraz bardziej ambitne cele przy bardzo szybkim rozwoju technologii i wysokich oczekiwaniach specjalistycznych pracowników, istotna jest rola przywódcy w budowie potencjału społecznego firmy. Niewątpliwie tworzenie warunków wyzwalających wśród pracowników ich wewnętrzne zaangażowanie stanowi imperatyw w budowaniu potencjału społecznego przedsiębiorstwa.
\end{abstract}

Cel badań. W artykule przeprowadzono analizę zależności między sytuacyjnym modelem przywództwa a realizowanym stylem kierowania. Celem artykułu jest przedstawienie kluczowych cech skutecznego przywódcy oraz identyfikacja oczekiwań pracowników względem postaw i działań kierownika-przywódcy.

Metodologia. W celu identyfikacji kluczowych cech przywódcy przeprowadzone zostały badania ankietowe wśród 156 pracowników z pięciu przedsiębiorstw. Badanie zostało przeprowadzone przy użyciu anonimowego kwestionariusza ankiety. Druga techniką badawczą był wywiad bezpośredni przeprowadzony z przedstawicielami kadry zarządzającej badanych przedsiębiorstw.

Kluczowe wnioski. Badanie wykazało grupę kluczowych warunków, które istotnie wpłynęły na budowanie stopnia zaangażowania pracowników w firmach. Wyniki badań pozwoliły także przybliżyć się do tematyki przywództwa w sensie praktycznym. Ocenie poddano m.in. relacje między przełożonym a podwładnymi, możliwości partycypacji w procesie decyzyjnym, a także oczekiwania wobec kierownika-przywódcy i reprezentowany przez niego styl kierowania. Przedstawiono kluczowe cechy skutecznego przywódcy oraz zidentyfikowano oczekiwania pracowników względem postaw i działań kierownika-przywódcy. Czynniki te wpływają na kształtowanie i efektywność przyjętego stylu kierowania w sytuacyjnym modelu przywódcy.

Słowa kluczowe: przywództwo, styl przywództwa, zaangażowanie organizacyjne. 